\title{
カーボンナノチューブの電界放射測定と 電界イオン顕微鏡による評価*
}

吉村 敏彦*1 ·稲見 和則*1 $\cdot$ 山下 洋司*1

（受理2003年11月 6 日，掲載決定2004年 1 月 10 日）

Field Emission Measurement and Evaluation

by Field Ion Microscope of Carbon Nanotube

\author{
Toshihiko YOSHIMURA*1, Kazunori INAMI*1 and Youji YAMASHITA*1 \\ ${ }^{* 1}$ Department of Mechanical Engineering, Kure National College of Technology \\ 2-2-11 Agaminami Kure, 727-8506 Hiroshima
}

(Received November 6, 2003, Accepted January 10, 2004)

\begin{abstract}
Using the simple sample which equipped a needlelike sample of tungsten with the carbon nanotube, V-I measurement of Multi-wall carbon nanotube (MWNT) was able to be performed and an FEM image and FIM image were able to be observed. In the measurement of the V-I characteristic, MWNT with low threshold value of voltage was found out. Further, in FEM observation, a five member ring which constitutes NT tip were recognized. Six member rings which constitute NT were also found in FIM observation.
\end{abstract}

\section{1. 緒言}

カーボンナノチューブ11は, 形状と導電性を利用した 用途開発が行われ, フィールドエミッションディスプレ 1 (FED) 用の電子銃や燃料電池の電極材料, 構造強 化材, 導電性添加材, 走査型プローブ顕微鏡の探針 ${ }^{2}$ 等 幅広い応用が期待されている ${ }^{3)}$. また，カーボンナノチ ューブからの電界放出については，1995年に初めて報告 され4-5)，1998年にナノチューブ電界放出電子源を有す る発光ディスプレイが試作された6).

針状プローブを用いたナノレベルの分析技術は，電界 電子放射顕微鏡 (Field Emission Microscopy, FEM), 電 界イオン顕微鏡 (Field Ion Microscopy, FIM) ${ }^{7)}$ ，アトム プローブ (Atom Probe, AP), 走査プローブ顕微鏡 $(\mathrm{SPM})$, 走査型アトムプローブ $(\mathrm{SAP})^{8)}$ へと様々な機 能を有する分析技術へと進歩を遂げてきた.

* 平成15年11月13日 第44回真空に関する連合講演会で発表

*1 吳工業高等専門学校機械工学科（干737-8506 広島県点市阿賀南 2 丁 目 2 番11号)
本研究では, 1991年に発見されて以来 ${ }^{1)}$, 様々な分野 で実用化が始まったカーボンナノチューブのV-I 特性 を調べるとともに，針状プローブの基本技術である FEM およびFIM で観察し検討を行った.

\section{2. 実験方法}

実験に使用したカーボンナノチューブは, 触媒分解法 で製作した多層ナノチューブ（MWNT，東京ブログレ スシステムズ製) である. Fig. 1 に示すように, 吳高専 の FIM-FEM 装置では, 試料の向きを $180^{\circ}$ 変えること により V-I 測定や FEM 像観察と, FIM 観察を切り替 えることができる.FEM 像観察および FIM 観察では, シェブロン型 MCPを備えたスクリーンを用いた，V-I 測定では, MCP の前に直径 $30 \mathrm{~mm}$ の平板電極を切換え 式で挿入し, 室温でエミッション電流を測定した。ま た, 試料と電極間の距離は $30 \mathrm{~mm}$ とした。また FIM 像 観察では, 試料を液体窒素温度むで泠却し, Ne ガスを 映像ガスとして用いた。

Fig. 2 に示すように, タングステン下地針状試料の先 


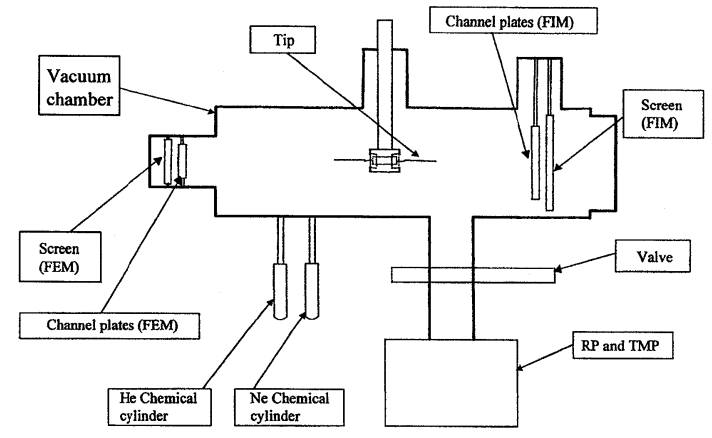

Fig. 1 FEM-FIM instrument.

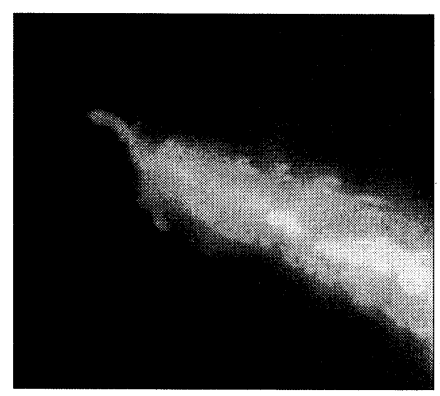

Fig. 2 MWNT specimen for FEM-FIM measurement.

端に， Cベースの電導性接着剤でナノチューブを装着し た. 平板試料にナノチューブを装着する場合と異なり, 針状下地金属にすることにより装着領域を限定すること が可能になり， 1 本の NT が装着した試料を作成するこ とができるようになる，通常タングステンの FEM · FIM 観察では, 先端の曲率半径が $100 \mathrm{~nm}$ 以下の鋭い針 状試料を作成するが, NTを装着する本研究では, 下地 金属のみでは観察されない曲率半径の大きい試料を用い た.な掞ナノチューブの装着は，2500倍まで拡大できる 光学顕微鏡で観察しながら行った.

\section{3. 実験 結 果}

Fig. 3 Kフェロセンーキシレンの混合ガス $(0.4 \mathrm{kPa})$ 中の触媒反応で生成した MWNTのV-I 特性を示す。 電流が流れ始める電圧閾值は，470 V と高い値になって いる.ここで, 電圧の昇圧と減圧のカーブが異なるの は, カーボンナノチューブの表面に存在した酸化膜の影 響があるものと考えられる. フェロセンーキシレンの混 合ガス $(2 \mathrm{kPa})$ 中の触媒反応で生成した MWNTのVI 特性を Fig. 4 に示す。閾値電圧は $60 \mathrm{~V}$ となり，0.4 $\mathrm{kPa}$ の場合に比べて非常に低い値になっている. 混合ガ

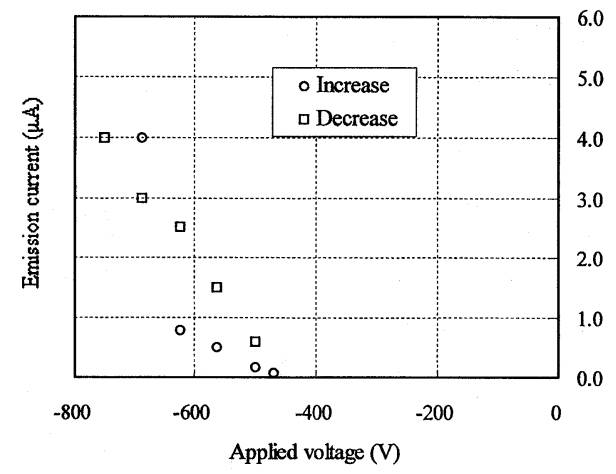

Fig. 3 V-I characteristic of MWNT. (Catalyst decomposition: $0.4 \mathrm{kPa}$ ferrocenexylene mixture gas)

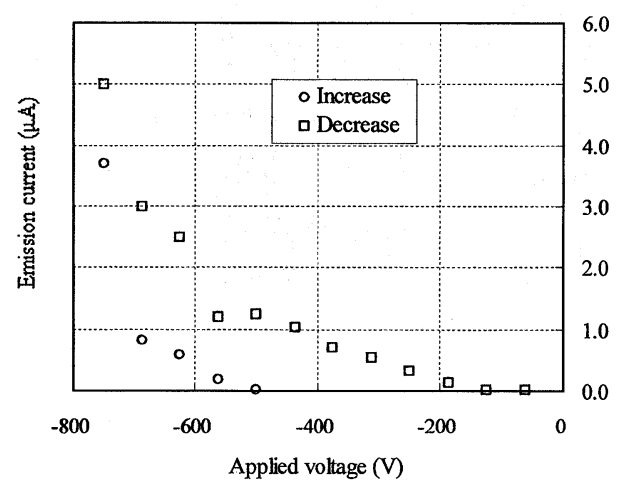

Fig. 4 V-I characteristic of MWNT. (Catalyst decompositon: $2 \mathrm{kPa}$ ferrocenexylene mixture gas)

ス圧によって生成される MWNTの相違が，如何なる メカニズムで $\mathrm{FE}$ 特性に差をもたらすかは今のところ不 明であるが，TEM写真等から判断すると, Fig. 4 の MWNT の方が直径や層数，開口，閉口等が影響してい るのではないかと推定される. 従来行われたシリコンエ ミッタ先端に成長させた SWNT の閾值電圧 ${ }^{9)}$ の值より も高いが，このような簡便な試料を用いて，大量生産が 可能な触媒反応により作成した多層ナノチューブの V-I 特性を測定できることが分かった，また，NTを装着す る下地を針状にすることにより，分析 NTを特定する ことが可能である.

Fig. 5 は, MWNT の FEM 像である（印加電圧-600 $\mathrm{V}$, 真空度 $\left.10^{-7} \mathrm{~Pa}\right)$. スクリーンの端で観察されている ため, 全体像は現れていないが，閉口NTを構成する 五角形リング(五員環)の一部が認められる. 本結果は, 従来の研究 ${ }^{10)}$ と一致する.しかしながら従来の研究で は, 五員環の中心が暗く, 隣接したリングが観察されて いる．本研究でこのような多数のリングが認められなか 


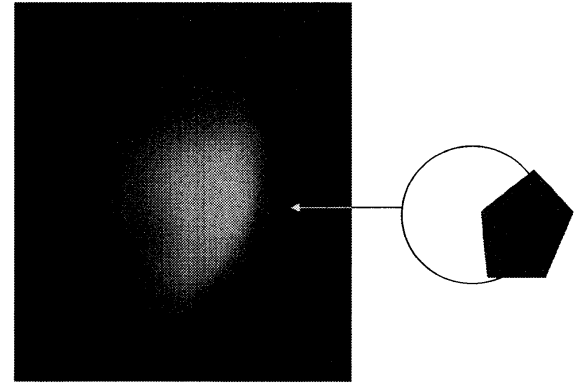

Fig. 5 FEM image of MWNT. (Back ground pressure: $2 \times 10^{-6} \mathrm{~Pa}$, Applied voltage: $-600 \mathrm{~V}$ )
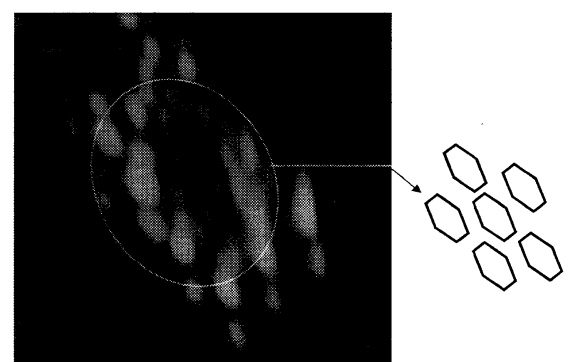

Fig. 6 FIM image of MWNT. (Imaging gas: Ne, gas pressure: $2 \times 10^{-3} \mathrm{~Pa}$, Applied voltage: +8000 $\mathrm{V})$

ったのは，NTを加熱処理（フラッシング）しなかった ためと考えられる. 本研究では, カーボンベースの電導 性接着材で装着しているため, 試料の加熱が制限され る.

Fig. 6 にMWNT の FIM 像を示す. 映像ガスとして He ガスを用いると，明確な MWNT の FIM 像を観察 することができなかった。これは，MWNTを構成する 炭素原子の蒸発電界が, He ガスのイオン化電界よりも 低かったためであると考えられる。な扔印加電圧は，+ $8 \mathrm{kV}$ で, $\mathrm{Ne}$ ガス圧は $2 \times 10^{-3} \mathrm{~Pa}$ であった。通常金属 や合金の FIM 観察では, 結晶構造の指数面に対応した リングパターンが観察される，ここで，針状試料先端は 電界蒸発により半球形状になり，その半球面は(110)面 や (100) 面等の低指数面, および高次の指数面から構成 される. また, 各指数面は個々の原子が円形に配列さ れ，同心円状に並んだパターンとなる.しかしながら本 研究のNTの場合では，そのような同心円状のリング パターンは見られない。これは，NTの原子配列が半球 状ではなく，円筒形状をしているためであると考えられ る. Fig. 6 において, 像の中心部や周辺部にナノチュー ブを構成する六方格子 (六員環) が観察される. NT は,
炭素原子が六角形状に並んだ六員環が組み合わさって構 成される円筒物質である. 個々の輝点はMWNTの側 面を構成する原子に相当し, 細長い像になっているのは NT の円筒側面が映像化されているためと考えられる.

FIM 像を構成する各輝点が縦長になっているのは, 先 端の電界分布が雨んでいることに起因する. しかしなが ら，この電界分布の歪みがカーボンナノチューブ自身の 断面方向の歪によるものかについては, 今後の検討課題 である. 以上のように，FIMを用いるとナノチューブ の原子配列の直接観察が可能であることが明らかになっ た.

今後は，針先の原子分布を立体的に観察することがで きる 3 次元アトムプローブで MWNT の水素のトラッ プ状況 ${ }^{11)}$ を評価する.さらに，ヘリウムと大気の混合ガ ス中のアーク放電で生成される球状物質についても検討 を進めて行きたい。

\section{4. よ め}

W下地針状試料にカーボンナノチューブを装着した 簡易な試料を用い，MWNT の V-I 測定を行い， FEM 像や FIM 像観察を観察することができた.

(1) V-I 特性の測定では, 閾值電圧の低い MWNT が 見出された。

(2) FEM 観察では，NT 先端を構成する五員環を観 察することができた。

（3） FIM 観察では，NT を構成する六員環が認められ た.

なお本研究は, 財ひろしま産業振興機構の研究助成を 受けて行ったものである.

\section{[文献 $]$}

1) S. Iijima: Nature, 354 (1991) 56.

2）大澤秀一 : Daiwa Institute of Research (2002-3).

3) H. Dai, J. H. Hafner, A. G. Rinzler, D. T. Colbert and R. E. Smalley: Nature, 384 (1996) 147.

4) A. G. Rinzler et al.: Science, 269 (1995) 1550.

5) W. A. de Heer, A. Chatelain and D. Ugarte: Science, 270 (1995) 1179.

6) Y. Saito, S. Uemura and K. Hamaguchi: Japanese Journal of Applied Physics, 37 (1998) 346.

7) E. W. Meoller: Z. Physik, 136 (1951) 131.

8) O. Nishikawa and M. Kimoto: Applied Surface Science, 76/77 (1994) 424.

9）松本和彦 (産総研)：日本経済新聞, 平成14年 4 月 5 日.

10) Y. Saito, K. Hata and T. Murata: Jpn. J. Appl. Phys., 39 (2000) L271.

11) T. Yoshimura and Y. Ishikawa: Journal of Vacuum Science \& Technology A, 204 (2002) 1450. 